\title{
KASUS CERAI GUGAT PADA ISTRI BERPENDIDIKAN TINGGI
}

\author{
Oleh: Sun Choirol Ummah, M.SI. \\ (Unit MKU Universitas Negeri Yogyakarta)
}

\begin{abstract}
Abstrak
Tingkat pendidikan yang rendah dan komitmen keluarga yang rapuh, seringkali memicu berbagai konflik dalam rumah tangga, utamanya terhadap perempuan. Banyaknya perempuan berpendidikan tinggi dewasa ini, tidak hanya membanggakan perempuan sendiri sebagai pelaku pendidikan, namun merambah pada lingkungan keluarga, lembaga pendidikan, para pemerhati kesetaraan gender hingga pemegang kebijakan pendidikan di tingkat daerah maupun nasional. Berbekal pendidikan tinggi, perempuan lebih memiliki akses yang luas di ranah publik. Banyak sekali perempuan telah mampu bersaing di hampir seluruh lini pekerjaan, sehingga kebijakan pemerintah pun kini mulai bergeser, tidak hanya mengacu pada kebijakan maskulinitas, walaupun berbagai bias masih saja ditemukan. Tingkat pendidikan yang tinggi, karir yang mapan, dan kesejahteraan yang terjamin merupakan tapakan sinergis dalam menata sebuah kehidupan rumah tangga. Namun, di pihak lain pendidikan tinggi yang dimiliki istri, justru menjadi bumerang terhadap meningkatnya kasus cerai gugat. Hal ini ditengarai akibat pengaruh budaya modern, kemandirian ekonomi istri, kejelian istri menangkap permasalahan keluarga, dan keberaniannya menyuarakan hak-haknya.
\end{abstract}

Kata kunci: pendidikan tinggi, kesetaraan gender, cerai gugat.

\section{Pendahuluan}

Pendidikan sejatinya merupakan bagian dari kehidupan manusia dan bersifat universal. Pendidikan berlangsung sejak lahir hingga akhir hayat dan dilaksanakan di lingkungan keluarga maupun di masyarakat dengan bantuan orang lain maupun secara mandiri. Pada masyarakat yang paling sederhana pun berlangsung proses pendidikan. Kemajuan di bidang pendidikan terkait dengan perkembangan kehidupan manusia. Dalam masyarakat yang telah maju, taraf pendidikan anggotanya lebih tinggi dibanding masyarakat tradisional (Sri Emi Yuli Suprihatin, 2008: 81).

Secara kodrati manusia memiliki hak untuk mengatur, membangun, dan mengarahkan destininya sendiri. Potensi itu pada dasarnya adalah untuk ditumbuhkembangkan melalui cultural struggle manusia secara terus menerus, baik secara individual maupun sosial. Cultural struggle itu tidak lain adalah pendidikan (Freire, 1984: 4). Di kalangan masyarakat modern, dorongan mengatur kehidupan 
untuk masa depannya jelas nampak pada kesadarannya memeroleh keterampilan atau jejang pendidikan yang lebih tinggi.

Jenjang pendidikan tinggi seperti dalam Undang-Undang RI No. 20 Tahun 2003, merupakan jenjang setelah pendidikan menengah yang mencakup program pendidikan diploma, sarjana, magister, spesialis, dan doktor yang diselenggarakan oleh perguruan tinggi. Jenjang pendidikan ini adalah lintas jenis kelamin, tingkat ekonomi, ras, dan sebagainya. Pandangan bahwa pendidikan tinggi hanya pantas dikenyam kaum Adam, menjadi bergeser bahwa kaum Hawa pun berhak menikmatinya. Pandangan seperti inilah yang senantiasa dihidupkan sampai saat ini karena kesetaraan dalam pendidikan disinyalir dapat mengurangi berbagai upaya yang merendahkan perempuan seperti marginalisasi, subordinasi, stereotipe (pelabelan yang merendahkan perempuan), dan kekerasan dalam rumah tangga, maupun beban kerja yang tidak berimbang.

Daerah Istimewa Yogyakarta, yang kental sekali dengan sebutan sebagai kota pelajar, memiliki tidak kurang dari 140 perguruan tinggi, baik negeri maupun swasta lengkap dengan variasi jenjang pendidikannya. Sebut saja misalnya Universitas Negeri Yogyakarta (UNY), Universitas Gadjah Mada (UGM), Universitas Islam Negeri (UIN) Sunan Kalijaga Yogyakarta, Universitas Muhammadiyah Yogyakarta (UMY), Universitas Atma Jaya Yogyakarta (UAJY), Universitas Pembangunan Nasional (UPN) Veteran, Universitas Kristen Duta Wacana (UKDW), dan masih banyak lagi perguruan tinggi lainnya, tidak terkecuali sekolah tinggi dan akademi seperti Amikom, STIPARY, dan AMPTA. Maraknya perguruan tinggi yang ada di Yogyakarta ini sudah barang tentu memberikan perubahan yang besar terhadap pola hidup masyarakatnya. Perubahan itu dapat dilihat tidak hanya pada semakin meningkatnya perekonomian, namun juga meningkatnya kualitas hidup, pola pikir, maupun akses informasi masyarakatnya terhadap pendidikan tinggi. Tumbuhnya kesadaran ini didukung pula oleh pandangan bahwa untuk mengejar tuntutan hidup yang semakin tinggi itu salah satu caranya pemenuhannya melewati jalur pendidikan.

Jenjang pendidikan tinggi yang diperoleh seseorang meniscayakan dirinya lebih mampu menghadapi problema hidup, lebih bertanggung jawab, dan lebih visioner dibandingkan dengan seseorang yang hanya lulus pendidikan dasar atau pun 
pendidikan menengah. Oleh karena itu, dalam memulai rajutan keluarga, seorang calon suami akan sangat berbangga hati bilamana mendapatkan calon istri yang berpendidikan tinggi, begitu pula sebaliknya dengan calon istri akan merasa mantap hatinya bila mendapatkan calon suami seorang yang berpendidikan tinggi pula. Tidak jarang gelar-gelar pendidikan tinggi yang mereka banggakan ini mereka sematkan dalam undangan pernikahan. Harapan lain yang diinginkan keduanya adalah dengan pendidikan yang setara tentunya akan menjadikan mereka mempunyai pola pikir yang minimal juga setara (Nasution, 2003: 48).

Di antara pasangan suami istri berpendidikan tinggi, banyak sekali yang mampu memertahankan perkawinan mereka, bahkan mampu mengukir prestasi kesarjanaan dalam rentang usia perkawinan mereka. Mereka mampu mengatur keseimbangan emosi dan kebutuhan hidup demi menjaga kelestarian perkawinan mereka. Namun, di satu sisi ternyata hal tersebut tidak merata dialami para sarjana lainnya. Mengutip data dari Pengadilan Agama Sleman, perceraian yang terjadi justeru didominasi kasus cerai gugat daripada cerai talak. Pada tahun 2007 saja, jumlah cerai talak 36 perkara dan cerai gugat 71 perkara, pada tahun 2008, jumlah cerai talak 42 perkara dan cerai gugat 73 perkara, sedang pada tahun 2009 jumlah cerai talak 17 perkara dan cerai gugat 84 perkara. Sedangkan bila dilihat dari tingkat pendidikan tinggi penggugat, pada tahun 2007 sebanyak 23 gugatan, tahun 2008 sebanyak 25 gugatan, dan pada tahun 2009 sebanyak 33 gugatan. Data yang ada juga menunjukkan bahwa mayoritas istri yang mengajukan gugatannya telah memiliki kemandirian ekonomi, baik sebagai karyawan, guru, dosen, walaupun juga dijumpai status istri sebagai ibu rumah tangga yang dalam kenyataannya memiliki indekos, maupun pemilik warung makan, dan sebagian kecil yang masih berstatus sebagai mahasiswa. Bila dicermati lebih lanjut, perceraian banyak terjadi pada kisaran lima hingga dua puluh tahun masa perkawinan. Faktor penyebab terbanyak adalah tidak adanya keharmonisan dalam rumah tangga (Ummah, 2010: 87-89).

Melihat data di atas, tulisan ini bermaksud menelusuri permasalahan mengapa banyak sekali istri berpendidikan tinggi melakukan cerai gugat. Begitu juga, apakah pendidikan tinggi yang diperoleh istri belum cukup digunakan sebagai bekal menjaga kelestarian keluarganya. 


\section{Kesetaraan Pendidikan}

Saat ini akses dan partisipasi perempuan dalam pendidikan masih tersisih dibanding laki-laki. Tahun 2004 saja, di Jawa Tengah, hasil penelitian yang dilakukan oleh Pusat Studi Wanita Universitas Negeri Semarang (PSW UNNES) dan PSW UNS Surakarta menemukan bahwa angka melek huruf perempuan di sana hanya 84,85\%, sedang laki-laki mencapai 92,63\%. Namun harus diakui bahwa jumlah perempuan yang telah mengenyam pendidikan di perguruan tinggi pada masa sekarang tentu lebih banyak daripada masa 70-80-an (Ainurrafiq dan Fahmi Arif, 2008: 1).

Seiring dengan terbukanya kesempatan itu terbentang pula harapan dan anganangan yang mungkin diraih. Sebagian perempuan telah bercita-cita bekerja di kantor dan meniti karir, bekerja di bidang manufaktur, entertainment, enterpreneurship, bidang pertanian, peternakan dan perikanan, di bidang kepariwisataan, serta peluang kerja lainnya, sebagian tidak ingin terikat oleh ruang dan waktu di belakang meja, sebagian ingin menjadi ibu rumah tangga yang berwawasan luas dalam mendidik anak dan berkeluarga, sebagian lagi tidak memaksakan diri harus ini atau itu tetapi lebih tergantung pada situasi yang ada (Ainurrafiq dan Fahmi Arif, 2008, 2).

Sejatinya peran perempuan dalam pembangunan juga masih sering diabaikan terutama di negara-negara berkembang. Posisinya dalam pembangunan masih sering di bawah laki-laki. Pemberdayaan perempuan diharapkan akan meningkatkan kemandiriannya. Kemandirian yang dimiliki oleh seorang perempuan, misalnya dalam bidang ekonomi dapat meningkatkan pendapatan rumah tangganya, dan secara tidak langsung meningkatkan income percapita suatu daerah (Eni Zuhni Khayati, 2008: 30).

Perempuan berpendidikan dan memiliki kemandirian ekonomi akan lebih memiliki akses informasi yang lebih baik daripada perempuan yang tidak sempat menambah ilmu pengetahuan dan mengembangkan diri serta wawasannya baik melalui pelatihan program-program pemberdayaan perempuan atau kegiatan lainnya karena disibukkan dengan berbagai pekerjaan, mulai dari pekerjaan rumah tangga yang tidak ada habis-habisnya, merawat dan mengasuh anak dari bangun tidur sampai anak tidur kembali, melayani suami, dan kesibukan yang lainnya. Kesibukan yang sangat padat dan masalah ekonomi inilah yang menjauhkan perempuan dari sumber- 
sumber informasi yang sesungguhnya sangat penting bagi kemandirian dirinya (Eni Zuhni Khayati, 2008: 32-33).

Sesungguhnya bila dicermati dalil naqli atau teks-teks (nash) yang ada, hak yang paling penting yang diberikan Islam kepada perempuan justru adalah hak pendidikan. Dalam hal ini, jika dilihat kembali sejarah pra-Islam, kultur dan budaya masyarakat jahiliyahlah yang ingin didekonstruksi oleh Islam. Islam datang memberikan penghargaan dan kesempatan kepada perempuan untuk mendapatkan pengetahuan yang sama dengan laki-laki. Sebab dalam Islam kemuliaan bukan diukur pada banyaknya harta, atau ukuran fisik dan kepantasan publik, tetapi justru diukur berdasarkan tingkat ketakwaan dan kapasitas keilmuannya. Allah swt. berfirman dalam QS. Al-Mujadilah (58): 11.

"Hai orang-orang beriman apabila kamu dikatakan kepadamu: "Berlapanglapanglah dalam majlis", maka lapangkanlah niscaya Allah akan memberi kelapangan untukmu. Dan apabila dikatakan: "Berdirilah kamu", maka berdirilah, niscaya Allah akan meninggikan orang-orang yang beriman di antaramu dan orang-orang yang diberi ilmu pengetahuan beberapa derajat. Dan Allah Maha Mengetahui apa yang kamu kerjakan.” (QS. Al-Mujadilah [58]: 11).

Hal senada ditegaskan kembali oleh Nabi saw. dengan menyatakan bahwa hanya dengan menuntut ilmulah kebodohan akan sirna, dan cara melawan kebodohan itu adalah dengan membuka selebar-lebarnya peluang menuntut ilmu. Beliau juga menyatakan bahwa menuntut ilmu pada konteks ini menjadi sebuah kewajiban yang harus dilaksanakan oleh umatnya, tanpa perbedaan jenis kelamin. Dalam salah satu hadis yang diriwayatkan oleh Anas bin Malik, Rasulullah saw. menegaskan:"Mencari ilmu itu wajib bagi setiap orang Islam laki-laki dan perempuan” (HR. Ibnu Majah, tt: hadis no. 3808).

Islam mendukung pendidikan perempuan dalam wilayah agama maupun sosial. Islam tidak mengenal prioritas bagi laki-laki di atas perempuan sehubungan dengan hak pendidikan. Laki-laki dan perempuan sama-sama didukung untuk memeroleh pendidikan. Semua ayat Alquran yang berkaitan dengan pendidikan dan yang menganjurkan untuk menuntut ilmu pengetahuan pun ditunjukkan secara setara baik kepada laki-laki maupun perempuan. 
Dalam hal pencapaian prestasi, Allah menegaskan dalam QS. An-Nahl (16): 97, “Barangsiapa yang mengerjakan amal saleh, baik laki-laki maupun perempuan dalam keadaan beriman, maka sesungguhnya akan Kami berikan kepadanya kehidupan yang baik dan sesungguhnya akan Kami beri balasan kepada mereka dengan pahala yang lebih baik dari apa yang telah mereka kerjakan." Ditekankan dalam ayat ini bahwa laki-laki dan perempuan dalam Islam mendapat pahala yang sama dan bahwa amal saleh harus disertai iman.

Selain itu, menurut ayat di atas dapat diuraikan lebih lanjut pada pencapaian prestasi seorang hamba baik laki-laki maupun perempuan yang tidak dibedakan. Seperti dalam firman Allah swt. QS. Ali Imran (3): 195, "Maka Tuhan mereka memperkenankan permohonannya (dengan berfirman): "Sesungguhnya Aku tidak menyia-nyiakan amal orang-orang yang beramal di antara kamu, baik laki-laki atau perempuan, (karena) sebagian kamu adalah turunan dari sebagian yang lain."

Maksud dari ayat di atas adalah sebagaimana laki-laki yang berasal dari lakilaki dan perempuan, maka demikian pula halnya perempuan berasal dari laki-laki dan perempuan. Kedua-duanya sama-sama manusia, tak ada kelebihan yang satu dari yang lain tentang penilaian iman dan amalnya. Dalam pandangan Nasaruddin Umar, ayat di atas mengisyaratkan konsep kesetaraan yang ideal dan memberikan ketegasan bahwa prestasi individual, baik bidang spiritual maupun urusan karier profesional tidak mesti diambil alih oleh satu jenis kelamin saja, akan tetapi bisa dicapai oleh dua belah pihak baik laki-laki maupun perempuan (Nasaruddin Umar, 2002: 23).

Di sisi yang sama persamaan hak antara lelaki dan perempuan tercermin dalam persamaan nilai kemanusiaan dan persamaan hak sosialnya, persamaan dalam tanggung jawab dan balasannya, yakni persamaan yang didasarkan kepada berbagai sisinya yang terpadu dalam asalnya, kesatuan tujuannya, dan perhitungan kelak pada hari kiamat (Hibbah Rauf Izzat, 1997: 50). Dalam konteks negara, taksatu pun perundang-undangan secara tekstual di negeri ini yang bisa dituduh sebagai sumber diskriminasi, bahkan sejak awal negara melakukan ratifikasi Konvensi Penghapusan Segala Bentuk Diskriminasi terhadap Perempuan menjadi UU No. 7 Tahun 1984 (Mustaghfiroh Rahayu, 2007: 29). 
Perempuan sebenarnya memiliki peran dan fungsi yang sangat strategis dalam keluarga dan masyarakat. Sayangnya banyak yang tidak bisa memainkan peran dan fungsinya dengan baik karena faktor kemiskinan dan salah satu penyebab utama terjadinya kemiskinan ini adalah rendahnya tingkat pendidikan perempuan. Oleh karena itu, ada dua aspek yang menjadi kunci utama untuk lebih memberdayakan perempuan, yaitu pendidikan dan ekonomi. Kebijakan dalam bidang pendidikan dan ekonomi bagi perempuan ini sangat perlu diperhatikan sebab jika ekonomi perempuan itu kuat, peran mereka dalam keluarga maupun masyarakat juga akan kuat. Begitu pula dengan pendidikannya, apabila perempuan memiliki pengetahuan yang luas dan tingkat pendidikan yang tinggi, peran mereka secara mikro dalam keluarga akan tinggi, bahkan peran sosial perempuan dalam masyarakat juga tinggi.

Pada tingkat keluarga sebagai unit dasar dalam membentuk masyarakat, persepsi yang tidak sama antar anggota keluarga dapat menimbulkan kesenjangan antara fakta dan harapan dalam mewujudkan keluarga yang aman tenteram bahagia sejahtera yang dapat menimbulkan banyak konflik dalam keluarga itu sendiri, sehingga dapat pula mengancam ketahanan keluarga. Yang perlu diperhatikan adalah konflik ekonomi dan nilai-nilai dalam keluarga karena dapat merapuhkan institusi keluarga serta menimbulkan gejolak sosial yang tidak diinginkan. Untuk mencegah konflik-konflik tersebut maka peranan pendidikan bagi perempuan sangat membantu untuk mengatasi masalah dan konflik-konflik tersebut (Eni Zuhni Khayati, 2008: 20).

\section{Faktor Penyebab Cerai Gugat}

Menurut UU No. 1 Tahun 1974 tentang Perkawinan, perkawinan adalah suatu ikatan yang sangat kuat atau mitsaqan galizhan. Namun, di sisi lain esensi perkawinan menyangkut pula unsur menaati perintah Allah dan melaksanakannya adalah suatu ibadah. Sebagai mitsaqan galizhan, ikatan perkawinan mempunyai tujuan untuk membentuk terwujudnya hubungan ikatan lahir batin antara seorang pria dan wanita sebagai suami istri dalam kehidupan keluarga (rumah tangga) yang bahagia dan kekal. Hal ini ditegaskan Allah swt. dalam QS. al-Nisa' (4): 21 yang artinya: “Bagaimana kamu akan mengambilnya kembali, padahal sebagian kamu telah bergaul (bercampur) dengan yang lain sebagai suami-isteri. Dan mereka (isteri-isterimu) telah mengambil dari kamu perjanjian yang kuat." 
Langgengnya ikatan perkawinan bukan saja merupakan keinginan setiap suami istri, namun hal itu juga dikehendaki oleh Islam. Akad nikah yang diadakan bertujuan untuk mewujudkan perkawinan selamanya, agar suami istri dapat membentuk sebuah keluarga sebagai tempat berlindung dan menikmati kasih sayang dan kebahagiaan serta tempat memelihara dan mendidik anak-anaknya. Oleh karena itu, keutuhan dan keharmonisan rumah tangga hendaknya selalu dijaga dan dilestarikan agar perkawinan bisa langgeng.

Sudah merupakan sebagian dari sifat manusia sekalipun dia telah mencapai segenap prestasi dan peningkatan keilmuannya, namun kelemahannya sebagai manusia tetap lebih menonjol. Karena itu, dalam kehidupan manusia ada saat-saat ketika tidak mungkin baginya untuk melanjutkan hubungan yang akrab dengan istrinya dan sebaliknya. Keadaan ini tentu saja berpengaruh terhadap keharmonisan dan keutuhan dalam rumah tangga. Akan tetapi, setiap permasalahan yang muncul selalu diiringi dengan solusi-solusi yang dapat dicari dan dipecahkan tergantung bagaiman individu yang bersangkutan menyikapi dan berusaha menyelesaikannya.

Masalah-masalah yang timbul dalam perkawinan yang dapat beresiko kepada perceraian, dapat diselesaikan dengan kemauan kedua belah pihak suami istri untuk mengadakan musyawarah, apabila usaha ini tidak berhasil maka suami istri hendaknya melakukan usaha yang lain misalnya dengan meminta bantuan orang lain untuk membantu menyelesaikan permasalahan yang mereka hadapi. Dalam melakukan usaha ini setiap pihak hendaknya melakukannya dengan sabar dan berhati-hati, namun apabila semua usaha telah dilakukan dan tidak mampu membuahkan hasil maka perceraian dapat dijadikan solusi terakhir. Hal ini dilakukan untuk menghindari persoalan yang ada agar tidak menjadi persoalan yang lebih besar lagi.

Dalam hal perceraian, Alquran tidak memberikan ketentuan yang mengharuskan suami untuk mengemukakan alasan untuk menjatuhkan talak kepada istrinya, demikian pula sebaliknya (M. Jamil Latief, 1985: 43). Apabila istri merasa haknya terabaikan atau istri menderita tekanan lahir batin dalam kehidupan rumah tangga atau istri tertekan jiwanya atau istri ditelantarkan nasibnya, maka sudah sewajarnya istri mengadukan halnya kepada hakim, setelah melalui jalur islah kekeluargaan tidak dapat diatasinya, guna memeroleh keadilan dan penyelesaian yang 
sebaik-baiknya. Oleh karena itu, istri berhak sepenuhnya mengadukan perihalnya kepada hakim yakni dengan mengajukan gugatan cerai kepada suaminya.

Beberapa alasan yang dapat dijadikan istri dalam mengajukan gugatan perceraian dalam pandangan Amir Syarifiddin adalah pertama, syikak yakni adanya pertengkaran antara suami istri yang tidak mungkin didamaikan, kedua, cacat, yakni cacat yang ada pada diri suami atau istri baik cacat jasmani maupun rohani, ketiga, ketidakmampuan suami memberi nafkah, keempat, suami gaib (al mafqud) yakni suami yang meninggalkan tempat tetapnya dan tidak diketahui ke mana perginya dan dimana berada dalam waktu yang sudah lama, dan kelima, melanggar perjanjian dalam perkawinan (Amir Syarifuddin, 2008: 245-252).

Zahri Hamid memberikan beberapa alasan yang dapat dijadikan istri dalam mengajukan gugatan perceraian. Pertama, terjadinya penipuan dalam akad perkawinan, kedua, adanya unsur paksaan terhadap diri istri dalam perkawinan atau ancaman terhadap dirinya, ketiga, suami melanggar ta'lik talak, keempat, suami menyalahi perjanjian perkawinan yang dibuat bersama pada waktu akad perkawinan berlangsung, kelima, timbulnya kemudaratan pada diri istri sebab suami tidak mau atau tidak mampu menyelenggarakan nafkah sedemikian rupa, keenam, suami bersengaja tidak memberi nafkah pada istri dan anak-anaknya, ketujuh, suami tidak mempergauli istrinya sedangkan kemungkinan untuk itu ada dan tersedia, kedelapan, suami menganiaya dan menyakiti badan istri sedemikian rupa sehingga membahayakan istri, kesembilan, suami mafqud, dan kesepuluh, suami dihukum penjara (Hamid, 1987: 90-91).

Sedangkan menurut Abdur Rahman I. Doi, ada beberapa alasan yang dapat dipergunakan oleh istri dalam menuntut cerai (khuluk) dengan wewenang hakim dalam hukum Islam yang bila istri memiliki hak tafriq maka suami tidak akan memeroleh ganti rugi ( $i w a d)$. Perceraian tersebut mungkin diberikan oleh hakim karena: pertama, perlakuan menyakitkan yang diterima oleh istri, kedua, tidak dipenuhinya kewajiban-kewajiban dalam ikatan tersebut, ketiga, sakit ingatan, keempat, ketidakmampuan yang tidak dapat disembuhkan, kelima, suami pindah tempat tinggal tanpa memberitahu istri, dan keenam, sebab-sebab lain yang menurut pendapat hakim dapat dibenarkan untuk bercerai (Doi, 1992: 108). 
Dalam UU No. 1 Tahun 1974 Pasal 39 disebutkan bahwa: "untuk melakukan perceraian harus ada cukup alasan bahwa antara suami istri itu tidak akan dapat hidup rukun lagi sebagai suami istri”. Dengan ketentuan ini maka perceraian harus didasarkan pada ketidakmungkinan terjadinya kerukunan hidup antar suami istri dalam kehidupan rumah tangga. Adapun ketidakrukunan dalam rumah tangga harus berdasarkan pada alasan yang dijelaskan dalam penjelasan Pasal 39 UU No. 1 Tahun 1974 Jo Pasal 19 PP No. 9 Tahun 1975, yakni: pertama, salah satu pihak berbuat zina atau menjadi pemabuk pemadat, penjudi, dan lain-lain sebagainya yang sukar disembuhkan; kedua, salah satu pihak meninggalkan yang lainnya selama 2 (dua) tahun berturut-turut tanpa izin pihak yang lain dan tanpa alasan yang sah atau karena hal lain di luar kemampuan; ketiga, salah satu pihak mendapat hukuman penjara 5 (lima) tahun atau hukuman yang lebih berat setelah perkawinan berlangsung; keempat, salah satu pihak melakukan kekejaman atau penganiayaan berat yang membahayakan terhadap pihak lain; kelima, salah satu pihak mendapat cacat badan atau penyakit yang mengakibatkan tidak dapat menjalankan pekerjaannya sebagai suami atau istri; dan keenam, antara suami dan istri terus menerus terjadi perselisihan dan pertengkaran dan tidak ada harapan untuk hidup rukun lagi dalam rumah tangga. Sementara itu, dalam Kompilasi Hukum Islam, di samping yang telah disebutkan di atas, masih ditambah dengan dua alasan lagi yaitu seperti yang termuat dalam pasal 116 poin (g) dan (h), sebagai berikut: ketujuh, suami melanggar taklik talak, dan kedelapan, peralihan agama atau murtad yang menyebabkan terjadinya ketidakrukunan dalam rumah tangga.

Sebagai implementasi dari kedelapan alasan di atas, Pengadilan Agama menglasifikasikan faktor penyebab terjadinya cerai gugat di antaranya: pertama, suami mengalami krisis moral yang disebabkan karena poligami tidak sehat, krisis akhlak, cemburu, kedua, meninggalkan kewajiban yang disebabkan karena kawin paksa, kesulitan ekonomi, tidak ada tanggung jawab, ketiga, menyakiti jasmani, yang meliputi kekejaman jasmani dan kekejaman mental, dan keempat terus menerus berselisih yang disebabkan karena faktor politis, gangguan pihak ketiga, dan tidak ada keharmonisan. Atas dasar berbagai faktor di ataslah biasanya para hakim Pengadilan Agama dapat memutuskan perkara perceraian yang diajukan oleh istri, yang biasanya 
faktor pemicu perceraian berkait kelindan antara satu faktor dengan faktor lainnya. Misalnya, dikabulkannya gugatan perceraian seorang istri disebabkan karena tidak adanya keharmonisan dalam rumah tangga, yang ditandai dengan terjadinya perselisihan terus menerus antara suami istri. Di saat tertentu, suami sebenarnya melakukan kekejaman baik fisik maupun psikis (merupakan faktor lainnya), karena mengalami depresi berat setelah di-PHK, hingga pada akhirnya suami tidak memiliki sumber ekonomi yang cukup (merupakan faktor yang berbeda) untuk menafkahi keluarganya. Dalam hal ini, biasanya seorang hakim ketika memutuskan perkara, mengambil faktor yang paling kuat dan paling sering dilakukan, serta yang memiliki paling rendah tingkat resikonya terhadap suami istri. Di luar itu, pengambilan keputusan akhir ini tentunya setelah melalui pemanggilan sidang berkali-kali dan berbagai mediasi yang dilakukan secara maksimal.

Kondisi cerai gugat yang meningkat pada tahun-tahun terakhir rupanya menjadi perhatian serius baik di kalangan praktisi hukum maupun para pemerhati perkawinan. Menanggapi maraknya cerai gugat yang dilakukan para istri berpendidikan tinggi, berdasar pada data yang telah disebutkan di atas, tingkat pendidikan yang tinggi, karir yang mapan, dan kesejahteraan yang terjamin, seharusnya merupakan tapakan sinergis dalam menata sebuah kehidupan rumah tangga. Namun pada sebagian lainnya, pendidikan tinggi yang dimiliki istri justru menjadi bumerang terhadap meningkatnya kasus cerai gugat. Hal ini ditengarai akibat pengaruh budaya modern, kemandirian ekonomi istri, kejelian istri menangkap permasalahan keluarga, dan keberaniannya menyuarakan hak-haknya.

Berangkat dari hasil temuan beberapa kasus cerai gugat di Pengadilan Agama Sleman dapat diungkap misalnya, cerai gugat istri berpendidikan tinggi yang diakibatkan oleh budaya modern yang mengedepankan teknologi dan menuntut semua permasalahan dapat diselesaikan secara cepat. Bahwa kesibukan yang padat, pekerjaan yang menumpuk, belum lagi kondisi emosional yang tidak stabil sangat mempengaruhi cara pandang istri terhadap permasalahan dalam keluarganya. Permasalahan dalam keluarga terkadang diselesaikan dengan melakukan kesalahan yang lain atau menempuh perceraian bila sudah tidak ditemukan kesepakatan untuk hidup rukun. Penegakan komitmen perkawinan bergeser pada pencapaian keinginan 
individualis masing-masing. Akan halnya pengaruh negativitas sarana komunikasi dan teknologi maya, memudahkan para istri untuk menghindari permasalahan keluarga ketika tidak mendapatkan hak-haknya dari suami, istri gampang melakukan selingkuh. Selayaknya suami istri meluangkan waktu mereka untuk saling introspeksi diri, tidak menjadi budak budaya modern, dan harus tetap menjaga komitmen perkawinan. Hidup berkeluarga merupakan berkumpulnya persamaan dan perbedaan, kebaikan dan keburukan antara suami istri, asal tidak terlalu tenggelam dalam perbedaan dan keburukan.

Bila senyatanya suami tidak mendapatkan kelayakan ekonomi untuk menghidupi keluarganya, sedangkan sang istri justeru yang banyak menyokong ekonomi tersebut, bahkan bila dibandingkan antara penghasilan istri dengan suami justru lebih besar penghasilan istri daripada suami, maka yang terjadi adalah kecemburuan pihak istri. Istri merasa diperas tenaganya untuk melakukan pekerjaanpekerjaan di wilayah publik maupun domestik. Kondisi seperti ini jika berlarut-larut tanpa ada komunikasi keduanya, istri akhirnya merasa jenuh dan sering berselisih paham yang akhirnya terjadilah gugatan perceraian.

Perubahan situasi dan kondisi menyebabkan istri juga mencari nafkah, padahal kewajiban formal mencari nafkah adalah suami. Mencari nafkah bagi istri merupakan tanggung jawab moral dan sosial, bukan karena darurat, tetapi perubahan konstruksi sosial yang menuntut terjadinya pola partisipasi laki-laki dan perempuan secara setara dalam berbagai sektor kehidupan. Oleh karena itu, agar relasi suami istri tetap harmonis, diperlukan perubahan mindset tentang nafkah dan juga pencitraan bahwa suami adalah pencari nafkah sedangkan istri yang membelanjakannya (Mufidah, 2008: 138). Konsep-konsep yang telah lama dianut mengenai kewajiban mengasuh anak mutlak dibebankan pada seorang ibu, dan laki-laki sebagai pencari nafkah yang disimbolkan untuk tidak bertahan di rumah tetapi mengais rejeki baik di sektor negeri ataupun swasta, sulit sekali dirubah karena belum adanya kemauan politik secara total dalam menciptakan kultur yang kondusif bagi terciptanya kesetaraan gender (Ratna Megawangi, 1999: 105). Melani Budianta juga berpandangan bahwa sulitnya mengubah tatanan yang ada karena banyak sistem yang sengaja dirancang untuk mempertahankan tatanan yang ada seperti sekarang, sehingga dominasi publik masih 
menguntungkan pihak laki-laki saja. Perempuan masih dipandang sebagai makhluk domestik by nature sementara partisipasi di ranah publik dicitrakan sebagai additional role sehingga hasil yang diperoleh juga ditempatkan sebagi nafkah tambahan bukan nafkah yang bisa diasumsikan "share" antara suami dan istri sehingga dua-duanya bisa saling melengkapi (Nurlia Dian Paramita, 2007:129).

Nafkah adalah harta kekayaan yang dititipkan Allah kepada sebuah keluarga dengan sarana bekerja. Karena itu bisa terjadi bahwa sumber penghasilan dari suami, bisa pula dari istri yang pada dasarnya untuk kesejahteraan bersama. Jika istri bekerja dan penghasilannya melebihi suami, suami tidak perlu khawatir dan cemburu bahkan merasa tertindas, demikian pula istri tidak perlu berubah karakter sebagai penindas. Sebaiknya, istri tetap santun, saling menghargai dalam kehidupan keluarganya, dan tidak mencederai komitmen perkawinan yang dibina bersama (Mufidah, 2008: 150).

Pada kasus tertentu, demi mempercepat proses perceraian, daripada harus mengikuti proses persidangan berkali-kali dan memakan waktu yang lama, adakalanya istri berpendidikan tinggi dan memiliki kemandirian ekonomi menyerahkan urusan gugatannya pada pengacara. Padahal untuk biaya mengurus perceraian sangat mahal, disinyalir minimal 15 juta rupiah. Terhadap istri yang memiliki kecukupan ekonomi, hal itu tetap saja ditempuh, yang penting bisa bercerai.

Pada kasus yang lain ditemukan bahwa istri yang berpendidikan tinggi lebih cerdas dan lebih jeli menangkap permasalahan keluarga. Dalam berita acara gugatannya ia lebih mampu mengungkapkan permasalahan keluarga secara panjang lebar, terperinci, dan tampak ilmiah di depan hakim. Sedangkan suami sebagai tergugat hanya diam terpaku karena tidak pernah berpikir sejauh dan sedalam itu permasalahan rumah tangganya. Istri memiliki standar ideal akan hak-hak yang harus diterima seperti yang digambarkan dalam pengetahuan yang diperolehnya baik bersumber dari kitab suci Alquran, hadis Nabi saw., maupun dari Undang-undang Perkawinan, padahal standar yang paling ideal ini hanya ada pada diri Nabi Muhammad saw. Suami istri pasti memiliki keperibadian (temperamen) dan karakter yang berbeda. Temperamen merupakan keperibadian yang sulit untuk diubah, sedangkan karakter dibentuk dari pengalaman hidup yang dapat diubah (Mufidah, 
2008: 98). Kebanyakan istri berpendidikan tinggi tidak telaten dan tidak sabar menghadapi temperamen dan karakter suaminya.

Kasus yang tidak kalah penting adalah keberanian istri menyuarakan hakhaknya. Keberanian ini berangkat dari permasalahan yang dialami istri dalam rumah tangganya yang ditumpu oleh pengetahuan tentang gender yang diperoleh baik melalui media cetak, elektronik, seminar-seminar, atau dari mata kuliah yang telah dikaji. Keberanian ini dapat pula tumbuh karena semangat istri menentang bentukbentuk penindasan suami. Istri yang berpendidikan tinggi mampu mengalkulasi seberapa banyak tugas kewajiban yang telah dilaksanakan dengan hak-hak yang telah diterima. Bila hak yang ditemukan istri ternyata lebih sedikit dari kewajiban yang dilakukannya, maka istri tidak menunda-nunda lagi untuk menempuh cerai gugat. Berdasarkan hasil pantauan LSM Rifka Annisa Women's Cresis Centre bahwa diduga tingginya angka perceraian yang diajukan pihak istri disebabkan oleh tingginya pemahaman tentang gender (http://harianjoglosemar.com/index.php?option=com content\&task=view\&id=26802).

\section{Kesimpulan}

Dari uraian di atas dapat disimpulkan bahwa perempuan yang berpendidikan tinggi secara tidak langsung mengangkat derajat perempuan pada umumnya, namun bukan berarti bias gender dengan serta merta terhapuskan. Pendidikan tinggi yang dimiliki istri tidak selayaknya menjadikan istri berada di atas angin, bahwa tidak menjadi permasalahan serius bila istri bercerai dari suaminya. Akibat pengaruh budaya modern, kemandirian ekonomi, dan kejelian istri menangkap permasalahan keluarga menjadikan istri berpendidikan tinggi lebih berani menyuarakan hak-haknya.

Terkait dengan hal tersebut, patut disadari bahwa manusia lahir dari masalah, hidup dengan masalah, bahkan mati pun adakalnya masih meninggalkan masalah. Permasalahan yang terjadi dalam perkawinan seharusnya disikapi sebagai proses pembelajaran seumur hidup, yang justru dengan masalah itulah istri menjadi lebih cerdas dan memiliki pribadi lebih matang. Selebihnya, istri tidak menganggap suami sebagai lawan yang harus dikalahkan di meja hijau. Perceraian benar-benar hanya 
merupakan emergency exit yang digunakan suami istri tatkala tidak menemukan solusi sama sekali yang dapat mempersatukan mereka.

\section{Daftar Pustaka}

Doi, Abdur Rahman I.. (1992). Perkawinan dalam Syari'at Islam. Alih bahasa oleh Basri Ina Asghari dan H. Wadi Masturi. Jakarta: Rineka Cipta.

Ainurrafiq dan Fahmi Arif. (2008). "Islam, Pendidikan dan Perempuan." Musawa, Vol. 6 (1): halaman 1.

Al-Ahadits al-Nabawiyyah.

Al-Quran al-Karim.

Amir Syarifuddin. (2008). Hukum Perkawinan Islam Indonesia antara Fiqh Munakahat dan Undang-Undang Perkawinan. Jakarta: Kencana.

Eni Zuhni Khayati. (2008). "Pendidikan dan Independensi Perempuan.” Musawa, Vol. 6 (1): halaman 30.

Freire, Paulo. (1984). Pendidikan sebagai Praktik Pembebasan, terj. A.A. Nugroho. Jakarta: Gramedia Pustaka Utama.

Hadis Ibnu Majah, Sahih Jami’ al-Sagir. Hadis no. 3808.

Hibbah Rauf Izzat. (1997). Wanita dan Politik Pandangan Islam. Bandung: Remaja Rosdakarya.

(http://harianjoglosemar.com/index.php?option=com_content\&task=view \&id=26802).

M. Jamil Latief. (1985). Aneka Hukum Perceraian di Indonesia. Jakarta: Ghalia Indonesia.

Mufidah Ch. 2008. Psikologi Keluarga Islam Berwawasan Gender. Malang: UIN Malang Press.

Mustaghfiroh Rahayu. (2007). Islam dan Gerakan Perempuan. Yogyakarta: LKiS.

Nasaruddin Umar. (2002). Qur'an untuk Perempuan. Jakarta: Jaringan Islam Liberal.

Nasution, Khoiruddin. (2003). "Signifikansi Kafaah dalam Upaya mewujudkan Keluarga Bahagia." Aplikasia, Vol. IV (1): halaman 48.

Nurlia Dian Paramita. (2007). "Jawaban Agama terhadap Perempuan." Perempuan Agama dan Demokrasi. M. Subkhi Ridho (ed). Yogyakarta: Lembaga Studi Islam dan Politik (LSIP). 
Ratna Megawangi. (1999). Membiarkan Berbeda? Sudut Pandang Baru tentang Relasi Gender. Bandung: Mizan.

Sri Emi Yuli Suprihatin. (2008). "Menggagas Pendidikan Enterpreneur dan Perempuan Mandiri." Musawa, Vol. 6 (1): halaman 81.

Sun Choirol Ummah. (2010). "Kasus Cerai Gugat Suami-Istri Berpendidikan Tinggi di Kecamatan Depok Sleman Yogyakarta Tahun 2007-2009." Tesis. Tidak diterbitkan.

Undang-Undang RI No. 20 Tahun 2003 tentang Sistem Pendidikan Nasional.

Undang-Undang RI No. 1 Tahun 1974 tentang Perkawinan.

Zahri Hamid. (1987). Pokok-pokok Hukum Perkawinan Islam dan Undang-undang Perkawinan di Indonesia. cet. 1. Yogyakarta: Bina Cipta.

\section{Biodata Penulis}

Sun Choirol Ummah, M.S.I. adalah dosen luar biasa Pendidikan Agama Islam di Universitas Negeri Yogyakarta. Ia menyelesaikan studi S-1 Jurusan Bahasa Arab, Fakultas Tarbiyah, IAIN Sunan Kalijaga Yogyakarta, lulus tahun 1995. Strata dua (S-2) Program Studi Hukum Islam, Konsentrasi Hukum Keluarga di UIN Sunan Kalijaga Yogyakarta diselesaikannya tahun 2010. Ia mulai menjadi dosen di UNY sejak tahun 2010 sampai sekarang. 